\title{
PENGARUH KARAKTERISTIK KOMITE AUDIT TERHADAP PENGAWASAN BANK \\ (Studi Kasus Pada Bank Pembangunan Daerah Seluruh Indonesia)
}

\author{
Syarifah Farra Annisa ${ }^{{ }^{*}}$, Rita Anugrah², dan Poppy Nurmayanti \\ ${ }^{1}$ Program Studi Magister Akuntansi Pasca Sarjana,Universitas Riau \\ ${ }^{2}$ Dosen Fakultas Ekonomi, Universitas Riau \\ E-mail : neesa_femme@yahoo.co.id
}

\begin{abstract}
The aim of this research is to show whether there is significant effect of competence, independence and integrity to effectiveness of bank supervision. The object of this research are the banking company incorporated in the Regional Development Bank (BPD) throughout Indonesia. The respondents are individuals at the audit committee team on Regional Development Bank (BPD) throughout Indonesia. The research method that was used is hypothesis testing with correlation analysis. Data collection in this research was by sending questioners directly and also by mail survey. From the 81 questioners only 40 questioners was returned, therefore the data was tested 40 respondents. The hypothesis test was by sing multiple regression method. The research find that there is no significant effect of competence and independence audit committee to effectiveness of bank supervision, however there is significant effect of integrity to effectiveness of bank supervision.

Keywords : Audit Committee, Competence, Independence, Integrity
\end{abstract}

\section{PENDAHULUAN}

Dalam perkembangannya, industri perbankan di Indonesia telah mengalami pasang surut. Krisis perbankan sejak pertengahan tahun 1997 berdampak pada buruknya kinerja disektor perbankan Indonesia yang mengakibatkan buruknya perekonomian negara (Kurniawati, et al. 2011). Menurut Tangkilisan (2003), belum diterapkannya good corporate governance (GCG) diprediksi menjadi faktor utama krisis yang terjadi di Indonesia.

Pada dasarnya prinsip GCG telah terimplementasikan pada perusahaan sejak awal pendirian perusahaan tersebut, seperti adanya organ - organ perusahaan (direksi dan komisaris) yang merupakan bukti telah diaplikasikannya good corporate governance dalam tataran yang minimal. Di Indonesia, organ organ perusahaan tersebut diatur didalam Undang - Undang No. 40 Tahun 2007 tetang Perseroan Terbatas. Berdasarkan Undang - Undang tersebut disebutkan bahwa sistem kepengurusan terdiri dari dua jenjang yang masing - masing melakukan fungsi kepengurusan dan fungsi pengawasan.

Dewan komisaris merupakan organ perusahaan yang bertugas melakukan fungsi pengawasan terhadap fungsi kepengurusan yang dilakukan oleh Direksi (Sutojo dan Aldridge, 2005). Untuk mendorong peran pengawasan dari dewan 
komisaris tersebut, maka dewan komisaris wajib membentuk komite - komite yang membantu dewan komisaris melakukan fungsi pengawasan. Adapun salah satu komite yang dibentuk oleh dewan komisaris adalah komite audit.

Beberapa penelitian mengenai keberadaan komite audit di Indonesia telah dilakukan. Penelitian yang dilakukan oleh Murtanto, et al (2005) yang menunjukkan bahwa kewenangan dan status komite audit, kompetensi komite audit yang dinilai dengan sejauh mana komite audit mempunyai latar belakang pendidikan akuntansi dan perbankan, independensi komite audit yang diukur dengan sejauh mana anggota komite audit tersebut merangkap manajemen, komunikasi yang dimiliki komite audit dengan satuan pengawas interen perusahaan, kurang mempunyai pengaruh yang signifikan terhadap efektifitas peranan komite audit. Anugerah (2011) menunjukkan bahwa variabel independensi, pegetahuan keuangan dan kemampuan menyelesaikan masalah mempengaruhi pertimbangan komite audit. Variabel pengetahuan keuangan merupakan mediator yang mempengaruhi variabel kemampuan menyelesaikan masalah terhadap pertimbangan komite audit.

Komite audit di perbankan dipandang sebagai wujud mekanisme pengendalian yang diharapkan dapat mengoptimalkan fungsi pengawasan. Namun dalam prakteknya komite audit di perbankan ternyata masih belum berjalan dengan efektif. Hal ini ditunjukkan dengan masih banyaknya bank bank yang dilikuidasi khususnya di Indonesia. Hal ini membuktikan bahwa aspek pengawasan di perbankan Indonesia masih sangat lemah. Terjadinya kasus kasus lemahnya pengawasan di perbankan tersebut membuka pertanyaan apakah karakteristik komite audit berpengaruh terhadap efektifitas pengawasan bank.

Terbentuknya komite audit merupakan salah satu media untuk meningkatkan efektifitas sistem pengendalian perusahaan. Seiring dengan berjalannya waktu, banyak harapan yang dibebankan pada komite audit tersebut, terutama pada kompetensi, independensi serta integritas komite audit. Melalui penelitian ini, peneliti ingin mengetahui apakah terdapat pengaruh yang signifikan antara kompetensi, independensi, dan integritas terhadap efektitiftas pengawasan yang dilihat pada bank.

\section{KERANGKA TEORI}

\section{Efektifitas Pengawasan Bank Oleh Komite Audit}

Bank berfungsi sebagai lembaga yang dipercaya untuk melayani segala kebutuhan keuangan dari dan untuk masyarakat (Judisseno, 2002). Dengan kegiatan usaha yang bergerak atas dasar kepercayaan, setiap pemangku kepentingan dibidang perbankan wajib menjaga kepercayaan masyarakat tersebut dengan menyelenggarakan pengelolaan atas dasar prinsip kehati - 
hatian (prudential banking). Sejalan dengan perkembangan dan kemajuan dunia usaha perbankan, maka diperlukan pengendalian interen bank yang merupakan suatu mekanisme pengawasan yang ditetapkan oleh manajemen pengelola bank, guna menjaga dan mengamankan harta kekayaan, menjamin tersedianya laporan yang lebih akurat, meningkatkan kepatuhan terhadap ketentuan perundangundangan yag berlaku, mengurangi dampak kerugian karena penyimpangan yang meliputi kecurangan dan/atau pelanggaran aspek kehati-hatian, meningkatkan efektifitas organisasi dan meningkatkan efisiensi biaya. Sasanti (2011) menyebutkan bahwa pengendalian interen yang dapat dilaksanakan salahsatunya dengan pembentukan komite audit yang efektif.

Kata "efektifitas" diartikan oleh beberapa penelitian yang meneliti tentang efektifitas dari komite audit adalah sebagai melaksanakan atau memenuhi tugas atau tanggung jawab khusus komite audit (Smith, 2003; Raghunandan et al, 2001; Millstein, 1999; Porter and Gendall, 1998; Rittenberg and Nair, 1994; Vanasco, 1994; Kalbers and Fogarty, 1993; Kalbers, 1992; Sommer, 1991; Jenkins and Robinson, 1985). Sedangkan Dezoort (1998) mendefinisikan efektifitas sebagai kemampuan secara kolektif suatu komite untuk memenuhi tujuan pengawasannya. Berdasarkan beberapa definisi efektifitas diatas, dapat disimpulkan bahwa efektifitas pengawasan yang dilakukan oleh komite audit dapat dilihat dari sejauh mana komite audit melaksanakan tugas dan tanggungjawabnya dalam mengawasi perusahaan.

Oleh karena komite audit dalam penelitian ini merupakan komite audit di perbankan yang tugas dan tanggungjawabnya diatur oleh Bank Indonesia, maka efektifitas pengawasan dari komite audit tersebut dapat diketahui dari sejauh mana anggota komite audit melaksanakan dan memenuhi tugas dan tanggungjawabnya menurut peraturan Bank Indonesia tersebut, yaitu Peraturan Bank Indonesia (PBI) Nomor 8/4/PBI/2006 tentang Pelaksanaan Good Corporate Governance Bagi Bank Umum.

\section{Karakteristik Komite Audit}

Komite audit mempunyai peran yang cukup vital dalam proses terlaksananya suatu mekanisme tata kelola perusahaan yang baik. Tentunya agar komite audit dapat menjalankan tugasnya dengan benar dan efektif, maka diperlukan kualifikasi-kualifikasi khusus yang memadai agar maksimal dalam menjalankan tugas dan tanggung jawabnya (Wardhani dan Joseph, 2010). Menurut Wardhani dan Joseph (2010), komite audit yang memiliki karakteristik yang baik diharapkan memiliki kemampuan untuk menjalankan tugas pengawasan dengan baik dengan membuat rekomendasi-rekomendasi yang baik pula untuk perusahaan.

Kompetensi merupakan salah satu kualifikasi yang seharusnya dipenuhi.

The Concise Oxford English Dictionary dalam Hassall, et al (1996) 
mendefinisikan kompetensi sebagai suatu kemampuan untuk melakukan tugas. Sedangkan Hassall, et al (1996) mendefinisikan kompetensi sebagai kemampuan untuk melakukan suatu standar yang diakui. Pengertian ini kemudian dikembangkan lagi yaitu orang yang berkompeten dalam pekerjaan atau profesi yang dianggap memiliki suatu keterampilan, pengetahuan dan pemahaman yang diterapkan dalam suatu organisasi. Pengetahuan tentang keuangan merupakan salah satu karakteristik kompetensi yang penting yang harus dimiliki oleh anggota komite audit (Morse, 2004 di dalam Anugerah, 2011), karena pengetahuan tentang keuangan dapat memberikan dasar yang baik bagi komite audit untuk mengkaji dan menganalisis informasi keuangan (Rahmat, et al, 2008).

Suatu pengetahuan tidak hanya dapat diperoleh melalui suatu pendidikan saja, namun juga dapat diperoleh melalui pengalaman (Singtongkul, 2010). Menurut Singtongkul (2010), pengalaman yang dimaksud dalam pengertian ini adalah suatu pengalaman yang berhubungan dengan keuangan, seperti pengalaman sebagai akuntan publik, auditor, petugas akunting dan kontroler. Oleh sebab komite audit dalam menjalankan fungsinya memungkinkan untuk menggunakan praktek akuntansi yang tinggi, maka pengalaman komite audit tersebut merupakan karakteristik yang juga harus dimiliki oleh anggota komite audit, karena anggota komite audit yang memiliki pengalaman lebih konsisten dalam membuat keputusan, memiliki pandangan lebih baik, dan mencapai kesepakatan lebih sering dari pada anggota yang tidak bepengalaman (DeZoort, 1998 Berdasarkan uraian tersebut diatas, maka dapat ditarik kesimpulan bahwa komite audit yang memiliki kompetensi, dalam hal ini pengetahuan dan pengalaman tentang keuangan, audit dan perbankan akan melaksanakan pengawasan bank secara efektif, sehingga dapat dibentuk hipotesis pertama penelitian ini yaitu :

$\mathrm{H}_{1} \quad$ : Terdapat pengaruh kompetensi komite audit terhadap efektifitas pengawasan bank

Kualifikasi lain yang sebaiknya dimiliki adalah independensi. Mulyadi (1998) mendefinisikan independensi sebagai bebas dari pengaruh, tidak dikendalikan oleh pihak lain, tidak tergantung pada orang lain. Selain itu The Oxford English Dictionary Online mendefinisikan independensi sebagai bebas dari subjektifitas atau pengaruh dari yang lain (Ferreira, 2008). Ketika komite audit mengaplikasikan pengertian independensi, maka akan tergambar dari kemampuan komite audit tersebut dalam mereview keputusan - keputusan yang dibuat oleh manajemen, mengevaluasi kinerja perusahaan dan bebas memberikan pendapat (judgement) dan berpandangan objektif dalam hal memenuhi tugas mereka sebagai pengawas perusahaan dengan baik (Ferreira, 2008). 
Rezaee (2009) didalam penelitiannya menjabarkan independensi komite audit yang dirangkum berdasarkan pedoman dan standar dari SEC antara lain mengharuskan setiap anggota komite audit untuk independen dengan (1) tidak menerima kompensasi apapun selain yang telah ditentukan sebagai anggota dewan; (2) tidak menyediakan jasa penasehat atau konsultan kepada perusahaan saat ini, perusahaan afiliasi maupun hubungan bisnis lainnya; (3) Tidak bekerja di perusahaan saat ini atau perusahaan afiliasi dalam lima tahun; (4) tidak menjadi anggota keluarga dekat dari eksekutif perusahaan atau afiliasinya dalam lima tahun terakhir. Independensi komite audit merupakan faktor penting bagi setiap anggota komite audit untuk melaksanakan fungsi pengawasan dan pemantauan terhadap laporan keuangan secara efektif (Anugerah, et al 2011). Berdasarkan uraian tersebut diatas, maka dapat ditarik kesimpulan bahwa komite audit yang memiliki independensi, akan melaksanakan pengawasan bank secara efektif, sehingga dapat dibentuk hipotsis kedua pada penelitian ini sebagai berikut :

$\mathrm{H}_{2} \quad$ : Terdapat pengaruh independensi komite audit terhadap efektifitas pengawasan bank

Selanjutnya salah satu karakeristik yang juga sangat penting yang harus dimiliki oleh komite audit adalah integritas. Stanford Encyclopedia of Philosophy (dalam Murtanto dan Maulana, 2005) mendefinisikan integritas merupakan kualitas karakter seseorang untuk bertindak konsisten sesuai dengan nilai - nilai serta kebijakan organisasi serta kode etik profesi. Menurut Mulyadi (2002) dalam penelitiannya tentang auditor menyatakan bahwa integritas adalah suatu elemen karakter yang mendasari timbulnya pengakuan profesional dimana intergitas ini merupakan kualitas yang mendasari kepercayaan publik dan merupakan dasar bagi auditor dalam menguji semua keputusan yang diambilnya. Dengan intergritas yang tinggi, maka auditor dapat meningkatkan kualitas hasil pemeriksaannya (Mulyadi, 2002). Uraian tentang integritas auditor diatas tentunya dapat dikaitkan dengan integritas anggota komite audit, mengingat pada dasarnya komite audit dan auditor memiliki fungsi yang sama yaitu fungsi pengawasan dan merupakan bagian dari internal perusahaan. Begitu pentingnya integritas ini sehingga BRC dalam Rezaee, et al (2003) merekomendasikan integritas menjadi salah satu karakter yang harus dimiliki oleh komite audit atas tanggungjawabnya sebagai pengawas perusahaan, karena dengan adanya integritas maka peran pengawasan akan dilakukan secara jujur, transparansi, berani, bijaksana dan bertanggungjawab yang pada akhirnya akan menguatkan kepercayaan publik. Berdasarkan uraian tersebut diatas, maka dapat ditarik kesimpulan bahwa komite audit yang memiliki integritas, akan melaksanakan pengawasan bank secara efektif, sehingga dapat dibentuk hipotesis ketiga dalam penelitian ini sebagai berikut : 
$\mathrm{H}_{3} \quad$ : Terdapat pengaruh integritas komite audit terhadap efektifitas pengawasan bank

\section{METODOLOGI}

Populasi yang digunakan dalam penelitian ini adalah anggota komite audit pada perusahaan perbankan yang tergabung dalam Bank Pembangunan Daerah (BPD) Seluruh Indonesia. Adapun jumlah anggota komite audit yang digunakan yaitu berjumlah 81 (delan puluh satu) orang yang berasal dari 26 (dua puluh enam) BPD berdasarkan pada Laporan Tahunan setiap BPD pada Tahun 2012. Teknik pengambilan sampel pada penelitian ini adalah sampling jenuh/sensus yaitu teknik penentuan sampel dimana semua anggota populasi digunakan sebagai sampel (Sugiyono, 2010) yang ditunjukkan pada Gambar 1. Alasan menggunakan sampling jenuh/sensus karena jumlah populasi yang relatif kecil dengan jumlah sampel penelitian ini sebanyak 81 (delapan puluh satu) sampel.

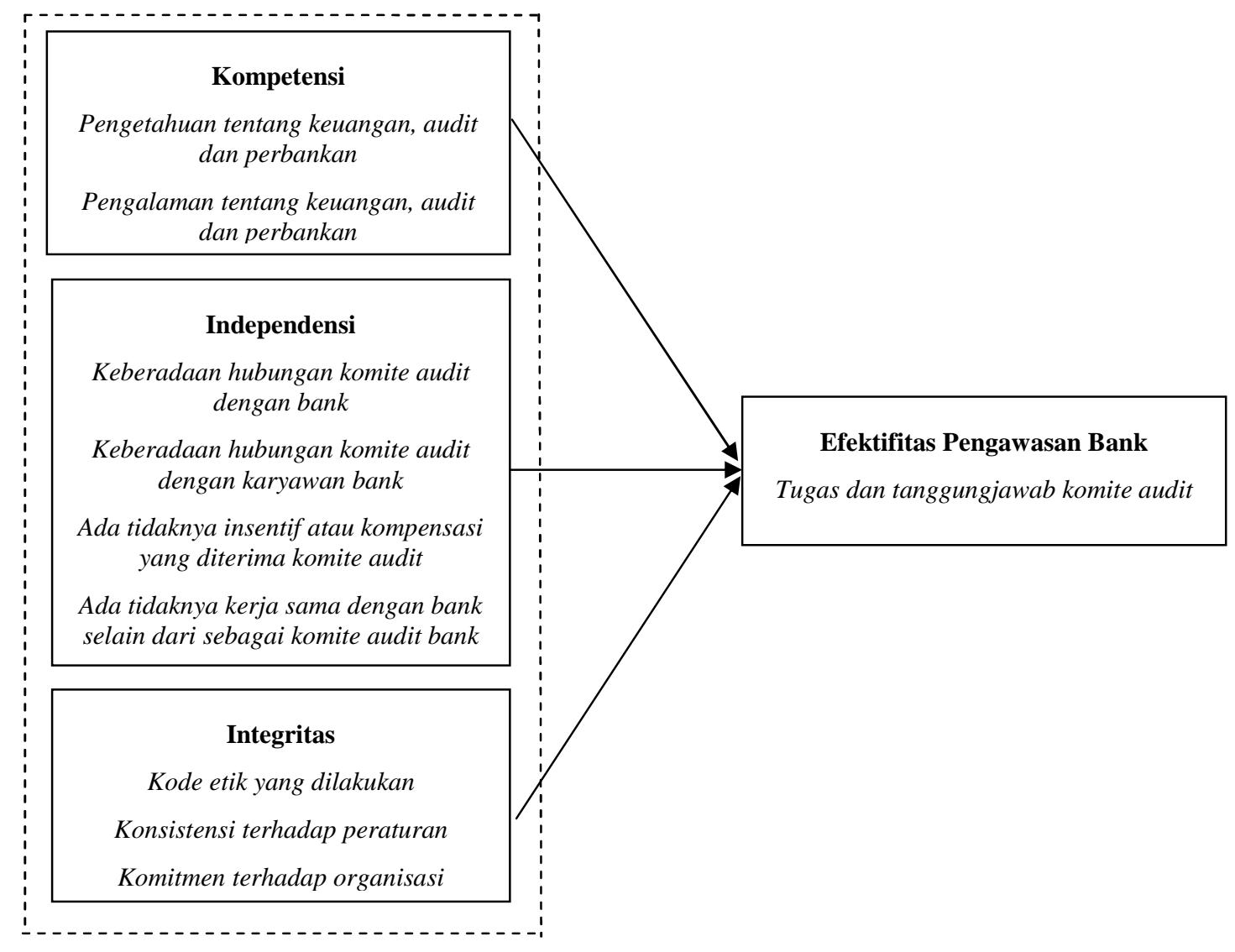

\section{Definisi dan Pengukuran Variabel}


Variabel terikat dalam penelitian ini adalah efektifitas pengawasan bank oleh komite audit. Efektifitas dalam konteks komite audit diartikan sebagai melaksanakan atau memenuhi tugas atau tanggung jawab khusus komite audit (Smith, 2003; Raghunandan et al, 2001; Millstein, 1999; Porter and Gendall, 1998; Rittenberg and Nair, 1994; Vanasco, 1994; Kalbers and Fogarty, 1993; Kalbers, 1992; Sommer, 1991; Jenkins and Robinson, 1985). Sedangkan dalam konteks efektifitas pengawasan bank, diartikan sebagai kemampuan secara kolektif suatu komite untuk memenuhi tujuan pengawasannya (Dezoort, 1998). Indikator yang digunakan untuk mengukur efektifitas pengawasan bank oleh komite audit berdasarkan Peraturan Bank Indonesia (PBI) Nomor 8/4/PBI/2006. Kumpulan pernyataan pada variabel efektifitas pengawasan bank diadaptasi dan dimodifikasi berdasarkan penelitian yang telah dilakukan oleh Murtanto, et al (2005) dengan menggunakan skala likert bernilai Sangat Tidak Setuju (STS) dengan skor 1, Tidak Setuju (TS) dengan skor 2, Netral (N) dengan skor 3, Setuju (S) dengan skor 4 dan Sangat Setuju (SS) dengan skor 5.

Variabel independen pada penelitian ini adalah :

1. Kompetensi $\left(\mathrm{X}_{1}\right)$, yaitu orang yang berkompeten dalam pekerjaan atau profesi yang dianggap memiliki suatu keterampilan, pengetahuan dan pemahaman yang diterapkan dalam suatu organisasi (Hassall, et al, 1996). Kompetensi komite audit diukur berdasarkan indikator yang sesuai dengan Peraturan Bank Indonesia (PBI) Nomor 8/4/PBI/2006 (Murtanto, et al., 2005). Pertanyaan menggunakan model skala Guttman, diberi nilai 2 untuk jawaban "ya", dan 1 untuk jawaban "tidak".

2. Independensi $\left(\mathrm{X}_{2}\right)$, yaitu diartikan sebagai bebas dari subjektifitas atau pengaruh dari yang lain (Ferreira, 2008; The Oxford English dictionary online). Kumpulan pertanyaan pada variabel independensi diadaptasi berdasarkan indikator penelitian yang telah dilakukan oleh Anugerah, et al (2011) dengan dimodifikasikan berdasarkan Peraturan Bank Indonesia (PBI) Nomor 8/4/PBI/2006 . Pertanyaan menggunakan model skala Guttman, diberi nilai jawaban "ya" bernilai 1 dan "tidak" bernilai 2.

3. Integritas $\left(\mathrm{X}_{3}\right)$, yaitu mengharuskan seseorang untuk bersikap jujur dan berterus terang tanpa harus mengorbankan rahasia, dapat menerima kesalahan yang tidak disengaja dan perbedaan pendapat yang jujur, tidak dapat menerima kecurangan atau peniadaan prinsip (Mulyadi, 2002). Didalam Keputusan Bapepam No. KEP-29/PM/2004, integritas dari setiap anggota dapat dilihat melalui kewenangan komite audit untuk mengakses catatan atau informasi tentang karyawan, dana, aset serta sumber daya perusahaan lainnya yang berkaitan dengan pelaksanaan tugasnya. Indikator yang digunakan untuk mengukur integritas komite audit antara lain diadaptasi berdasarkan penelitian yang telah dilakukan oleh Murtanto, et al (2005). Pertanyaan menggunakan skala modifikasi dari model skala likert, 
dengan nilaia jawaban Sangat Tidak Setuju (STS) dengan skor 1, Tidak Setuju (TS) dengan skor 2, Netral (N) dengan skor 3, Setuju (S) dengan skor 4 dan Sangat Setuju (SS) dengan skor 5 .

\section{Teknik Analisis}

Teknis analisis yang digunakan untuk menguji hipotesis pada penelitian adalah model regresi berganda (multiple linear regression). Sebelum dilakukan analisis regresi, terlebih dahulu dilakukan uji asumsi klasik yaitu uji normalitas, uji multikolinearitas, uji heteroskedastisitas, uji linearitas. Model yang digunakan dalam penelitian ini adalah :

$$
\mathrm{EPB}_{\mathrm{i}}=\mathrm{a}+\mathrm{b}_{1} \mathrm{KOMPET}_{\mathrm{i}}+\mathrm{b}_{2} \mathrm{INDEP}_{\mathrm{i}}+\mathrm{b}_{3} \mathrm{INT}_{\mathrm{i}}+\mathrm{i}
$$

Di mana :

$\mathrm{EPB}_{\mathrm{i}} \quad=$ Efektifitas Pengawasan Bank

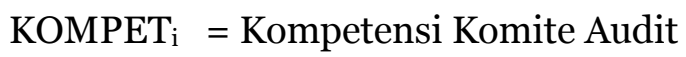

INDEP $_{\mathrm{i}}=$ Independensi Komite Audit

$\mathrm{INT}_{\mathrm{i}} \quad=$ Integritas Komite Audit

$a$ dan $b_{1}$ serta $b_{2}$ dan $b_{3} \quad=$ Konstanta

i $\quad=$ Error

\section{HASIL PENELITIAN}

\subsection{Hasil Uji Statistik Deskriptif}

Tabel 1. memperlihatkan statistik deskriptif dari variabel - variabel penelitian dalam persamaan yang menguji pengaruh karakteristik komite audit dan efektifitas pengawasan bank.

Dari hasil pengujian statistik deskriptif, rata - rata EPB oleh komite audit di BPD seluruh Indonesia adalah 68.6750 dari keseluruhan rata - rata EPB komite audit. Dimana EPB minimum 58.00 dan maksimum sebesar 80.00. Dengan rata - rata EPB sebesar 68.6750 maka dapat dikatakan komite audit yang memiliki EPB dibawah 68.6750 tidak efektif dalam mengawasi bank. Berdasarkan pengolahan data terdapat 21 responden yang EPB dibawah 68.6750.

Rata - rata proporsi untuk KOM pada komite audit di BDP seluruh Indonesia adalah 9.9500. Dimana KOM minimum 8.00 dan maksimum sebesar 12.00. Dengan rata - rata KOM sebesar 9.9500 maka dikatakan komite audit yang memiliki KOM dibawah 9.9500 tidak memenuhi kompetensi sebagai komite audit. Berdasarkan pengolahan data terdapat 15 responden yang tidak memenuhi kompetensi sebagai komite audit 
Rata - rata proporsi untuk IND komite audit di BPD seluruh Indonesia sebesar 13.6750. Dimana yang terendah bernilai 12.00 dan yang tertinggi bernilai 14.0o. Dengan rata - rata IND 13.6750 maka dapat dikatakan komite audit yang memiliki IND dibawah 13.6750 tidak memenuhi independensi sebagai komite audit. Berdasarkan pengolahan data terdapat 12 responden yang tidak memenuhi independensi sebagai komite audit

Rata - rata INT komite audit di BPD seluruh Indonesia adalah 20.1250 dari total komite audit. Dimana INT minimum 17.00 dan maksimum sebesar 25.00. Dengan rata - rata INT sebesar 20.1250 maka dapat dikatakan komite audit yang memiliki INT dibawah 20.1250 tidak memenuhi integritas sebagai komite audit. Berdasarkan pengolahan data terdapat 15 responden yang tidak memenuhi integritas sebagai komite audit.

\section{Hasil Uji Validitas dan Uji Reliabilitas}

Pengujian validitas instrumen penelitian, dilihat dari kolom corrected item - Total Correlation dari hasil output uji reliabilitas (Azwar, 2003). Jika r hitung dari r table dan nilai positif, maka butir pertanyaan tersebut valid (Azwar, 2003).

Pada Tabel 2 uji validitas di atas terlihat bahwa nilai Corrected Item-Total Correlation untuk butir - butir pertanyaan tentang efektifitas pengawasan bank berkisar antara 0.258 sampai dengan 0.800 dan bernilai positif dengan tingkat indeks daya diskriminasi $\geq 0.25$, kecuali untuk pertanyaan 14 (empat belas) yang memiliki nilai Corrected Item-Total Correlation sebesar 0.051. Namun dari hasil uji validitas secara umum semua pertanyaan mengenai efektifitas pengawasan bank adalah valid.

Uji reliabilitas dilakukan dengan melihat hasil dari Cronbach's Alpha Coefficient. Jika menilai Cronbach's Alpha Coefficient lebih besar dari o.6 (Azwar, 2003). Adapun berdasarkan hasil analisis penelitian yang telah dilakukan diketahui nilai reliabilitas $(\alpha)=0.873$ yang ditunjukkan pada variabel efektifitas pengawasan bank. Dengan demikian koefisien alpha variabel ini menunjukkan reliabilitas yang baik dan diterima.

\subsection{Hasil Uji Asumsi Klasik}

Distribusi normal diperoleh melalui pengujian Kolmogorov-Smirnov Test atau $\mathrm{KSz} \geq 0.01$ atau 0.05. Berdasarkan analisis multikoliniersitas diketahui bahwa ketiga variabel bebas (KOM, IND, INT) terhadap variabel terikat (EPB) menunjukkan TOL > 0.1 dan nilai VIF < 10. Maka, hasil yang diperoleh dapat disimpulkan bahwa tidak terdapat multikolinearitas dalam penelitian ini. Uji heteroskedastisitas didapatkan nilai $\mathrm{R}^{2}$ sebesar 0.175. sehingga $\mathrm{c}^{2}$ hitung $=40 \mathrm{x}$ $0.175=7$, sedangkan $\mathrm{c}^{2}$ tabel adalah sebesar 55.758, yang diperoleh dari tabel chisquare dengn degree of freedom $(n-1)=39$ dengan signifikansi 0.05 atau $5 \%$. 
Oleh karena $\mathrm{c}^{2}$ hitung $(7)<\mathrm{c}^{2}$ tabel (55.758), maka dapat disimpulkan tidak terjadi heteroskedastisitas dalam model penelitian ini. Hasil uji Linearitas pada masing - masing variabel menunjukkan pada Deviation from Linearity adalah o.661. Hal ini menunjukkan bahwa variabel kompetensi bersifat linear terhadap variabel efektifitas pengawasan bank (Sig $0.661>0.05$ ). Hasil pada Tabel 5 menunjukkan nilai Sig. pada Deviation from Linearity adalah 0.142. Hal ini menunjukkan bahwa variabel independensi bersifat linear terhadap variabel efektifitas pengawasan bank (Sig $0.142>0.05$ ). Hasil pada Tabel 6 menunjukkan nilai Sig. pada Deviation from Linearity adalah o.638. Hal ini menunjukkan bahwa variabel integritas bersifat linear terhadap variabel efektifitas pengawasan bank (Sig $0.638>0.05$ ).

\subsection{Hasil Uji Hipotesis}

Setelah melakukan pengujian asumsi klasik, normalitas, multikolinearitas dan heteroskedastisitas perlu dilakukan pengujian selanjutnya yaitu analisis model regresi dengan menggunakan analisis uji $\mathrm{F}$ guna menjawab hipotesis penelitian. Berdasarkan hasil uji F yang telah dilakukan pada Tabel 7. Hasil regresi menunjukkan bahwa nilai $\mathrm{F}$ sebesar 2.872 dengan nilai signifikansi $p$ sebesar 0.050 atau $p \leq 0.05$. Hasil ini mengindikasikan bahwa model regresi dapat mengagambarkan pengaruh variabel independen secara bersama - sama terhadap variabel dependen dengan cukup baik sehingga model penelitian ini valid untuk digunakan.

Berdasarkan Tabel 8 dapat dilihat bahwa nilai Adjusted $R^{2}$ untuk hasil regresi adalah sebesar 0.126 atau $12.6 \%$. Hal ini menunjukkan bahwa variabel bebas yaitu karakteristik komite audit berupa kompetensi, independensi dan integritas komite audit menjelaskan besarnya kontribusi variabel tersebut terhadap variabel terikat yaitu efektifitas pengawasan bank. Sedangkan sisanya sebesar $87.4 \%$ dipengaruhi oleh faktor - faktor lain yang tidak dimasukkan di dalam penelitian, seprti variabel umur, jumlah kehadiran komite audit dalam rapat dan pengambilan keputusan, komposisi jumlah komite audit, dan lain-lain..

Inteprestasi dari setiap variabel independen hasil regresi dijelaskan seperti berikut ini :

\section{Pengaruh kompetensi komite audit terhadap efektifitas pengawasan bank}

Dari hasil regresi pada Tabel 9, dapat diinterprestasikan bahwa tingkat kompetensi komite audit tidak mempunyai pengaruh yang signifikan terhadap efektifitas pengawasan bank. Hal ini terjadi karena kompetensi yang dimiliki oleh komite audit tersebut belum tentu dapat mendukung pemahaman komite audit dalam menjalankan tugas dan tanggungjawabnya dalam mengawasi bank. Selain itu, kurangnya kesadaran komite audit dalam menjalankan tugas dan tanggungjawabnya sebagai komite audit yang sesuai dengan peraturan yang telah 
ditetapkan dapat juga mengindikasikan bahwa pengawasan bank tidak berjalan secara efektif. Dengan signifikansi sebesar o.619 ( $p \geq 0.05)$, dapat disimpulkan bahwa, hipotesis $\left(\mathrm{H}_{1}\right)$ tidak terbukti (ditolak) sedangkan hipotesis null $\left(\mathrm{H}_{01}\right)$ terbukti (diterima)

\section{Pengaruh independensi komite audit terhadap efektifitas pengawasan bank}

Dari hasil regresi pada Tabel 10, dapat diinterprestasikan bahwa independensi komite audit tidak mempunyai pengaruh yang signifikan terhadap efektifitas pengawasan bank. Hal ini mungkin disebabkan karena pembentukan komite audit yang independen hanya bertujuan untuk memenuhi regulasi yang dikeluarkan oleh Bank Indonesia maupun peraturan lainnya sehingga tidak dapat mempengaruhi efektifitas pengawasan bank.. Dengan signifikansi sebesar 0.316 ( $p \geq 0.05$ ), maka dapat disimpulkan bahwa hipotesis $\left(\mathrm{H}_{2}\right)$ tidak terbukti (ditolak) sedangkan hipotesis null $\left(\mathrm{H}_{\mathrm{o} 2}\right)$ terbukti (diterima)

\section{Pengaruh integritas komite audit terhadap efektifitas pengawasan bank}

Dari hasil regresi pada Tabel 11, dapat diinterprestasikan bahwa integritas komite audit mempunyai pengaruh yang signifikan terhadap efektifitas pengawasan bank. Artinya bahwa komite audit yang memiliki integritas yang tinggi akan lebih mampu melakukan pengawasan bank secara efektif dibandingkan dengan komite audit yang tingkat integritasnya rendah. Hal ini sejalan dengan penelitian yang dilakukan oleh Wibowo (2009) dalam penelitiannya pada responden auditor menunjukkan bahwa auditor yang memiliki integritas yang tinggi akan lebih mampu memberikan opini audit yang lebih wajar dan lebih baik berkaitan dengan going concern suatu entitas dibandingkan dengan auditor dengan integritas yang lebih rendah. Dengan tingkat signifikansi sebesar $0.012(p \leq 0.05)$, maka dapat disimpulkan bahwa hipotesis $\left(\mathrm{H}_{3}\right)$ terbukti (diterima) sedangkan hipotesis null $\left(\mathrm{H}_{\mathrm{O}_{3}}\right)$ tidak terbukti (ditolak)

\section{KESIMPULAN, IMPLIKASIDAN KETERBATASAN PENELITIAN}

Berdasarkan hasil pengujian guna melihat pengaruh karakteristik komite audit yaitu kompetensi komite audit, diketahui bahwa tingkat kompetensi komite audit tidak mempunyai pengaruh yang signifikan terhadap efektifitas pengawasan bank.. Hal ini kemungkinan dapat terjadi dikarenakan kompetensi yang dimiliki oleh komite audit tersebut belum tentu dapat mendukung pemahaman komite audit terhadap tugas dan tanggungjawabnya dalam mengawasi bank. Selain itu, kurangnya kesadaran komite audit untuk melaksanakan tugas dan tanggungjawabnya sebagai komite audit bank sesuai 
dengan peraturan yang telah ditetapkan dapat juga mengindikasikan bahwa pengawasan bank tersebut tidak berjalan secara efektif.

Berdasarkan hasil pengujian guna melihat pengaruh karakteristik komite audit yaitu independensi komite audit, diketahui bahwa independensi komite audit tidak mempunyai pengaruh yang signifikan terhadap efektifitas pengawasan bank. Hal ini mungkin disebabkan karena pembentukan komite audit yang independen hanya bertujuan untuk memenuhi regulasi yang dikeluarkan oleh Bank Indonesia maupun peraturan lainnya sehingga tidak dapat mempengaruhi efektifitas pengawasan bank. Berdasarkan hasil pengujian guna melihat pengaruh karakteristik komite audit yaitu integritas komite audit, diketahui bahwa integritas komite audit mempunyai pengaruh yang signifikan terhadap efektifitas pengawasan bank. Artinya bahwa komite audit yang memiliki integritas yang tinggi akan lebih mampu melakukan pengawasan bank secara efektif dibandingkan dengan komite audit yang tingkat integritasnya rendah.

Selama melakukan penelitian, terdapat beberapa keterbatasan yang ditemukan sehingga membatasi kesempurnaan penelitian ini yaitu sampel yang digunakan untuk penelitian ini relatif terbatas, penelitian ini hanya menggunakan data tahun 2012 , memungkinkan terdapat beberapa faktor yang diamati terabaikan.

Penelitian ini diharapkan dapat memberikan kontribusi bagi pihak pihak yang berkepentingan seperti perusahaan perbankan bank khususnya bank - bank yang tergabung dalam Bank Pembangunan Daerah (BPD) serta bank bank non BPD kaena pada prinsipnya setiap perusahaan perbankan memiliki bidang bisnis yang sama sehingga penelitian ini dapat membantu pihak - pihak tersebut dalam menyusun dan merumuskan kebijakan khususnya terkait dengan komite audit dalam hal meningkatkan efektifitas pengawasan bank.

Bagi peneliti selanjutnya yang akan melakukan penelitian sejenis ataupun berhubungan dengan penelitian ini memperbanyak sampel yang digunakan, memperbanyak jumlah variabel bebas untuk mendukung penelitian selanjutnya misalnya dengan menambah faktor - faktor lain seperti jumlah pertemuan/rapat yang diadakan oleh komite audit, jumlah komite audit dalam suatu perusahaan, kebijakan akuntansi serta sistem audit yang digunakan oleh perusahaan dan Sebaiknya penelitian selanjutnya tidak hanya melakukan penelitian terbatas pada Bank Pembangunan Daerah (BPD) saja, namun perbankan nasional lainnya (non $-\mathrm{BPD})$.

\section{REFERENSI}


Abott, L., Parker, S., Gary Peters., (2004)., "Audit committee characteristics and restatement"., Auditing: A joural of Practice \& Theory Vol. 23, No. 1 pp. 69-87

Abott. L. J, Park. Y, S. Parker, (2000), "The effect of audit committee activiy and independence on corporate fraud", Managerial Finance, Vol. 26 Iss: 11 pp 55-68

Anugerah.R, Iskandar. T.M, Zuraidah M.S, (2011), "Conflict of opinion on accounting policy judgement: independence, knowledge and problem solving abilty of audit committees in Malaysia”, Intenational Journal of Bussiness Governance and Ethics, Vol.6, No. 4 pp. 341-358

Arens, et al, (2006), “Audit An Integrated Approach”, 8th Edition, Simon Co, New Jersey

Azwar, Saifuddin. (2003). “Metode penelitian”. Pustaka Pelajar, Yogyakarta

Azwar. S, (1999), “Validitas dan rentabilita”, Pustaka Belajar : Yogyakarta

Badan Pengawas Pasar Modal (BAPEPAM) Surat Edaran No. 03/PM/2000 Tentang Komite Audit

Bank Indonesia No. I/6/PBI/1999 tentang Penugasan Direktur Kepatuhan (Compliance Director)

Blue Ribbon Committee (BRC). (1999). "The report and recommendation of The Blue Ribbon Committee on the improving the effectiveness of corporate audit committee". New York Stock Exchange and National Association of Securities Dealers, New York

DeZoort, F.T. (1998). "An analysis of experience effect on audit committee members "oversight judgements". Accounting, Organization and Society, 23 (1), 1-22

DeZoort, FT dan Salterio SE. (2001). "The effect of corporate governance experience and financial reporting and audit knowledge on audit committee member's judgement”. Auditing : A Journal Practice \& Theory, Vol. 20, No. 2, pp. 31-47

Ferreira. I, (2008), "The effect of audit committee composition and structure on the performance of audit committees", Meditari Accountancy Research, Vol. 16 Iss: 2 pp. 89-106

Ghozali. I, 2005, "Aplikasi analisis multivariate dengan program spss", Universitas Diponegoro. Cetakan VI.

Hassall. T, Dunlop. A dan Lewis. S. (1996). "Internal audit education: exploring professiona; competence". MCB University Press : Managerial Auditing Journal 11/5 pp. 28-36

http://www.forumsains.com/ilmu-ekonomi-dan-manajemen/kasus-bankcentury di browsing tanggal 17 September 2012

Ikatan Akuntan Indonesia, (2001), "Standar profesional akuntan publik". Jakarta: Salemba Empat

Judisseno R, (2002), "Sistem moneter dan perbankan di Indonesia", PT. Gramedia Pustaka Utama : Jakarta 
Kalber. L \& Folgy. T, (1993), "Audit committee effectiveness : an empirical investigation of the contribution of power", Auditing A Journal of Practice \& Theory, Vol. 12, No. 1. Spring.

Keputusan Ketua BAPEPAM Nomor KEP-29/PM/2004 Peraturan Bapepam Nomor IX.I.5. Tahun 2004 tentang "Pembentukan dan pedoman pelaksanaan komite audit".

Keputusan Menteri Badan Usaha Milik Negara No. 103/MBU/2002 Tentang "Pembentukan Komite Audit Bagi Badan Usaha Milik Negara

Kurniawati. E. P, Nugroho. P.I, Milka K, (2011), “Tingkat akuntabilitas laporan keuangan melalui media internet pada industri perbankan yang terdaftar di Bursa Efek Indonesia”, Seminar Ilmiah Nasional, Vol 4, Oktober 2011, Lembaga Penelitian Universitas Gunadarma: Jakarta.

Mulyadi, (2002), “Auditng”, Edisi Keenam, Salemba Empat : Jakarta

Murtanto \& Edi. M, (2005), "Pengaruh Indepedensi, Integritas dan Kompetensi Terhadap Efektivitas Peranan Komite Audit”, Jurnal Bisnis \& Manajemen Vol 5 No. 2131-148, Fakultas Ekonomi. Universitas Trisakti : Jakarta

Peraturan Bank Indonesia (PBI) No. 5/8/PI/2003 Tentang Penerapan Manajemen Risiko Bagi Bank Umum

Peraturan Bank Indonesia (PBI) No. 8/44/PBI/2006 Tentang pelaksanaan good corporate governance bagi bank umum

Peraturan Bank Indonesia (PBI) Nomor 1/6/PBI/1999 tentang "Penugasan direktur kepatuhan (complience director) dan penerapan standar pelaksanaan fungsi audit interen interen bank umum".

Peraturan Bank Indonesia (PBI) Nomor 14/14/PBI/2012 tentang Transparansi dan Publikasi

Peraturan Bank Indonesia (PBI) Nomor 6/10/PBI/2004 tentang, "sistem tingkat kesehatan bank"

Peraturan Bank Indonesia (PBI) Nomor 8/4/PBI/2006 tentang Pelaksanaan Good Corporate Governance Bagi Bank Umum

Raghunandan K, Read WJ. (2001). "The state of audit committees”. Journal of Accountancy, 191, pp. $57-60$

Rahmat. M.M, Iskandar. T.M dan Saleh, N.M. (2008). "Audit committee characteristics in financially distressed and non-distressed companies”. Managerial Auditing Journal Vol 24 No. 7 pp. 624-638

Rezaee, Olibe dan George Minmier, (2003), "Improving corporate governance: the role of audit committee disclosures", Managerial Auditing Journal, Vol. 18 Iss:6 pp. 530-537

Sasanti D, (2011), "Kemandirian komite audit bank umum yang berbentuk badan usaha milik negara go public dalam rangka pencapaian konsep good corporate governance", Jurnal Hukum Bisnis dan Investasi, Dialogia Iuridicia pp. 18-26; Jakarta

Sawyer, L. B., A. D. Mortimer., H. S. James, (2005), "Sawyer's internal auditing: the practice of modern internal auditing”, $5^{\text {th }}$ Edition, Altamonte Springs, Florida: The Institute of Internal Auditor, Inc 
Singtokul, Ong-Arcd. (2010). "Episodic knowledge and judgement in audit an audit committee member task: experimental evidence". Dissertation, Georgia Institute of Technology.

Smith, R. Sir. (2003). "Audit committees combined code guiance: A Report and proposed guidance by an FRC apoointed group". Financial Reporting Council: London

Stanford Encyclopedia of Philosophy. (2011). "Integrity". The Metaphysics Research Lab Stanford University. Stanford. http://plato.stanford.edu/archives/spr2012/entries/integrity

Sugiyono. (2010). "Statistika untuk penelitian". Alfabeta, Bandung

Surat Edaran Bank Indonesia No. 6/23/DPNP/2004 Perihal "Sistem Penilaian Tingkat Kesehatan Bank Umum".

Surat Edaran Bank Indonesia No. 27/8/UPPB/1995 tanggal 31 Maret 1995

Sutojo., S dan Aldridge., John E, (2005), “Good corporate governance, tata kelola perusahaan yang sehat”, PT. Damar Mulia Pustaka : Jakarta

Tangkilisan. Hassel Nogi, 2003, "Mengelola kredit berbasis good corporate governance”, Penerbit Balairung \& Co Hal. 16 : Yogyakarta

Uma Sekaran, (2006), "Metodologi penelitian untuk bisnis", Salemba Empat : Jakarta

Undang - Undang No. 40 Tahun 2007 tetang Perseroan Terbatas

Undang - Undang Nomor 10 Tahun 1998 tentang perubahan Undang - Undang Nomor 7 Tahun 1992 Tentang Perbankan

Wardhani, R dan Joseph, H. (2010). "Karakteristik pribadi komite audit dan praktik manajemen laba”. Simposium Nasional Akuntansi XIII: Purwokerto

Wibowo. A. (2009). "Analisis efek moderasi lama hubungan kerja dan integritas pada pengaruh independensi auditor terhadap opini audit going concern”. Media Ekonomi \& Manajemen Vol. 20. No. 2

Zulaikha, Pamudji S, Hadi B, Kiswara E, Rahardja., (1999)., "Faktor - faktor yang mempengaruhi peranan efektifitas komite audit pada perusahaan perbankan”., Fakultas Ekonomi; Universitas Diponegoro : Semarang 
Tabel 1: Statistik Deskriptif

\begin{tabular}{|l|c|c|c|c|c|}
\hline \multicolumn{1}{|c|}{ Variabel } & N & Min & Max & Mean & Std Deviasi \\
\hline EPB & 40 & 58.00 & 80.00 & 68.6750 & 5.54417 \\
\hline KOM & 40 & 8.00 & 12.00 & 9.9500 & 1.13114 \\
\hline IND & 40 & 12.00 & 14.00 & 13.6750 & 0.52563 \\
\hline INT & 40 & 17.00 & 25.00 & 20.1250 & 1.92404 \\
\hline
\end{tabular}

Sumber : Hasil Data Olahan Dengan Program SPSS 17.0, 2013

\section{Tabel 2: Uji Validitas Butir - Butir Pertanyaan Tentang Efektifitas Pengawasan Bank}

\begin{tabular}{|c|c|c|c|}
\hline No & Pertanyaan & \begin{tabular}{|c|} 
Corrected \\
Item - Total \\
Correlation
\end{tabular} & Keterangan \\
\hline$\overline{1}$ & $\begin{array}{l}\text { Komite Audit di bank anda melakukan review terhadap laporan } \\
\text { perkembangan perencanaan audit yang telah disetujui secara berkala } \\
\text { setiap tiga bulan }\end{array}$ & 0.528 & Valid \\
\hline 2 & $\begin{array}{l}\text { Komite Audit di bank anda melakukan diskusi atas ringkasan laporan } \\
\text { internal audit dengan Pemimpin/Kepala SKAI perusahaan }\end{array}$ & 0.264 & Valid \\
\hline 3 & $\begin{array}{l}\text { Komite Audit di bank anda melakukan review terhadap perkembangan } \\
\text { pelaksanaan rekomendasi yang dikeluarkan oleh SKAI untuk Direksi }\end{array}$ & 0.258 & Valid \\
\hline 4 & $\begin{array}{l}\text { Komite Audit di bank anda melakukan review terhadap fungsi internal } \\
\text { audit secara keseluruhan setiap tahun }\end{array}$ & 0.637 & Valid \\
\hline 5 & $\begin{array}{l}\text { Komite Audit di bank anda melakukan review terhadap ruang lingkup dan } \\
\text { perencanaan audit yang telah dibuat oleh KAP }\end{array}$ & 0,360 & Valid \\
\hline 6 & $\begin{array}{l}\text { Komite Audit di bank anda melakukan review terhadap laporan auditor } \\
\text { yang dibuat oleh KAP }\end{array}$ & 0,387 & Valid \\
\hline 7 & $\begin{array}{l}\text { Komite Audit di bank anda melakukan review terhadap prinsip dan } \\
\text { praktek akuntansi serta perkiraan akuntansi yang digunakan perusahaan } \\
\text { dalam laporan keuangan triwulan dan tahunan }\end{array}$ & 0,585 & Valid \\
\hline 8 & $\begin{array}{l}\text { Komite Audit di bank anda melakukan review terhadap saran, komentar, } \\
\text { penyesuaian serta klasifikasi yang digunakan dalam laporan keuangan } \\
\text { triwulan dan tahunan dari auditor independen }\end{array}$ & 0,355 & Valid \\
\hline 9 & $\begin{array}{l}\text { Komite Audit di bank anda ikut memastikan bahwa penyajian laporan } \\
\text { keuangan triwulan dan tahunan perusahaan mudah untuk dipahami oleh } \\
\text { pengguna }\end{array}$ & 0,653 & Valid \\
\hline 10 & $\begin{array}{l}\text { Komite Audit di bank anda ikut memastikan jika informasi yang terdapat } \\
\text { dalam laporan keuangan perusahaan disajikan secara relevan sesuai } \\
\text { dengan kebutuhan pengambilan keputusan }\end{array}$ & 0,616 & Valid \\
\hline 11 & $\begin{array}{l}\text { Komite Audit di bank anda melakukan review justifikasi yang digunakan } \\
\text { perusahaan terhadap asumsi materiality }\end{array}$ & 0,681 & Valid \\
\hline 12 & $\begin{array}{l}\text { Komite Audit di bank anda memastikan semua informasi dalam laporan } \\
\text { keuangan perusahaan bebas dari kesalahan, netral, bebas dari bias }\end{array}$ & 0,800 & Valid \\
\hline 13 & $\begin{array}{l}\text { Komite Audit di bank anda memastikan laporan keuangan perusahaan } \\
\text { sudah mewakili semua transaksi atau peristiwa yang terjadi }\end{array}$ & 0,714 & Valid \\
\hline 14 & $\begin{array}{l}\text { Komite Audit di bank anda telah melakukan pemantauan dan evaluasi } \\
\text { pelaksanaan tindak lanjut direksi atas hasil temuan SKAI, KAP dan hasil } \\
\text { pengawasan Bank Indonesia guna memberikan rekomendasi kepada } \\
\text { dewan komisaris }\end{array}$ & 0,051 & Tidak Valid \\
\hline 15 & $\begin{array}{l}\text { Komite Audit di bank anda menyerahkan laporan evaluasi ruang lingkup, } \\
\text { akurasi dan efektifitas biaya, independensi dan obyektifitas KAP kepada } \\
\text { dewan komisaris }\end{array}$ & 0,772 & Valid \\
\hline 16 & $\begin{array}{l}\text { Komite Audit di bank anda saat ini telah memenuhi ketentuan Bank } \\
\text { Indonesia yang berlaku yaitu tentang Transparansi kondisi Keuangan } \\
\text { dalam penunjukkan Akuntan Publik dan Kantor Akuntan Publik }\end{array}$ & 0,562 & Valid \\
\hline
\end{tabular}

Sumber : hasil data olahan dengan program SPSS 17.0, 2013 
Tabel 3: Hasil Uji Multikolinearitas

Coefficients $^{\mathrm{a}}$

\begin{tabular}{|c|c|c|c|c|c|c|c|c|}
\hline & & \multicolumn{2}{|c|}{$\begin{array}{c}\text { Unstandardized } \\
\text { Coefficients }\end{array}$} & \multirow{2}{*}{$\begin{array}{c}\begin{array}{c}\text { Standard } \\
\text { Coeff }\end{array} \\
\text { Beta }\end{array}$} & \multirow[b]{2}{*}{$\mathrm{t}$} & \multirow[b]{2}{*}{ Sig. } & \multicolumn{2}{|c|}{ Collinearity Statistics } \\
\hline \multicolumn{2}{|c|}{ Model } & B & Std. Error & & & & Tol & VIF \\
\hline 1 & (Const) & 113.657 & 24.185 & & 4.700 & .000 & & \\
\hline & KOM & -.441 & .742 & -.090 & -.593 & .557 & .994 & 1.006 \\
\hline & IND & -1.369 & 1.619 & -.130 & -.845 & .403 & .968 & 1.033 \\
\hline & INT & -1.087 & .442 & -.377 & -2.462 & .019 & .971 & 1.030 \\
\hline
\end{tabular}

a. Dependent Variable: EPB

Sumber : data olahan dengan program SPSS 17.0

Tabel 4: Uji Linearitas Variabel Kompetensi $\left(\mathrm{X}_{1}\right)$

\begin{tabular}{|c|c|c|c|c|c|c|c|}
\hline \multicolumn{8}{|c|}{ ANOVA Table } \\
\hline & & & $\begin{array}{c}\text { Sum of } \\
\text { Squares }\end{array}$ & df & $\begin{array}{c}\text { Mean } \\
\text { Square }\end{array}$ & $\mathbf{F}$ & Sig. \\
\hline \multirow[t]{5}{*}{$\mathrm{EPB} * \mathrm{KOM}$} & \multirow{3}{*}{$\begin{array}{l}\text { Between } \\
\text { Groups }\end{array}$} & (Combined) & 57.502 & 4 & 14.376 & .441 & .778 \\
\hline & & Linearity & 4.908 & 1 & 4.908 & .151 & .700 \\
\hline & & $\begin{array}{l}\text { Deviation from } \\
\text { Linearity }\end{array}$ & 52.594 & 3 & 17.531 & .538 & .660 \\
\hline & \multicolumn{2}{|c|}{ Within Groups } & 1141.273 & 35 & 32.608 & & \\
\hline & \multicolumn{2}{|l|}{ Total } & 1198.775 & 39 & & & \\
\hline
\end{tabular}

- Independensi $\left(\mathbf{X}_{2}\right)$

Tabel 5: Uji Linearitas Variabel Independensi $\left(X_{2}\right)$

ANOVA Table

\begin{tabular}{llrrrrr}
\hline & & \multicolumn{1}{c}{$\begin{array}{c}\text { Sum of } \\
\text { Squares }\end{array}$} & df & $\begin{array}{c}\text { Mean } \\
\text { Square }\end{array}$ & \multicolumn{1}{c}{ F } & Sig. \\
\hline EPB * IND Between & (Combined) & 124.882 & 2 & 62.441 & 2.151 & .131 \\
Groups & Linearity & 59.616 & 1 & 59.616 & 2.054 & .160 \\
& Deviation from & 65.266 & 1 & 65.266 & 2.249 & .142 \\
& Linearity & & & & & \\
Within Groups & 1073.893 & 37 & 29.024 & \\
Total & 1198.775 & 39 & & \\
\hline
\end{tabular}

- Integritas $\left(\mathbf{X}_{3}\right)$

Tabel 6: Uji Linearitas Variabel Integritas $\left(X_{3}\right)$

ANOVA Table

\begin{tabular}{lllrrrrr}
\hline & & & \multicolumn{1}{c}{$\begin{array}{c}\text { Sum of } \\
\text { Squares }\end{array}$} & df & \multicolumn{1}{c}{$\begin{array}{c}\text { Mean } \\
\text { Square }\end{array}$} & \multicolumn{1}{c}{ F } & \multicolumn{1}{c}{ Sig. } \\
EPB * & Between & (Combined) & 307.175 & 7 & 43.882 & 1.575 & .179 \\
INT & Groups & Linearity & 187.146 & 1 & 187.146 & 6.717 & .014 \\
& & 120.030 & 6 & 20.005 & .718 & .638 \\
& & Deviation from & & & & & \\
& Linearity & 891.600 & 32 & 27.862 & & \\
& & 1198.775 & 39 & & & \\
\hline
\end{tabular}


Tabel 7: Uji F Variabel Bebas (KOM, IND, INT) Komite Audit Terhadap Variabel Terikat (EPB) ANOVA $^{b}$

\begin{tabular}{rlrrrrr}
\hline \multicolumn{1}{l}{ Model } & Sum of Squares & df & Mean Square & F & Sig. \\
\hline 1 & Regression & 231.519 & 3 & 77.173 & 2.872 & $.050^{\mathrm{a}}$ \\
Residual & 967.256 & 36 & 26.868 & & \\
Total & 1198.775 & 39 & & & \\
\hline
\end{tabular}

a. Predictors: (Constant), INT, KOM, IND

b. Dependent Variable: EPB

Sumber : data olahan dengan program SPSS 17.0

Tabel 8: Uji F Kompetensi Komite Audit Terhadap EPB

ANOVA $^{b}$

\begin{tabular}{|c|c|c|c|c|c|c|}
\hline & Model & Sum of Squares & $\mathrm{df}$ & Mean Square & $\mathrm{F}$ & Sig. \\
\hline \multirow[t]{3}{*}{1} & Regression & 7.896 & 1 & 7.896 & .251 & $.619^{\mathrm{a}}$ \\
\hline & Residual & 1195.879 & 38 & 31.470 & & \\
\hline & Total & 1203.775 & 39 & & & \\
\hline
\end{tabular}

a. Predictors: (Constant), KOM

b. Dependent Variable: EPB

Sumber : data olahan dengan program SPSS 17.0

Tabel. 9 Uji F Independensi Komite Audit Terhadap EPB

ANOVA $^{b}$

\begin{tabular}{llrrrrr}
\hline \multicolumn{1}{l}{ Model } & Sum of Squares & df & & Mean Square & F & \multicolumn{1}{c}{ Sig. } \\
1 & Regression & 31.849 & 1 & 31.849 & 1.033 & $.316^{\mathrm{a}}$ \\
Residual & 1171.926 & 38 & 30.840 & & \\
Total & 1203.775 & 39 & & &
\end{tabular}

a. Predictors: (Constant), IND

b. Dependent Variable: EPB

Sumber : data olahan dengan program SPSS 17.0

Tabel . 10 Uji F Integritas Komite Audit Terhadap EPB

\begin{tabular}{rlrrrrr|}
\multicolumn{7}{c}{ ANOVA $^{\mathrm{b}}$} \\
\hline Model & Sum of Squares & $\mathrm{df}$ & Mean Square & F & \multicolumn{1}{c|}{ Sig. } \\
Regression & 186.009 & 1 & 186.009 & 6.945 & $.012^{\mathrm{a}}$ \\
Residual & 1017.766 & 38 & 26.783 & & \\
Total & 1203.775 & 39 & & &
\end{tabular}

a. Predictors: (Constant), INT

b. Dependent Variable: EPB

Sumber : data olahan dengan program SPSS 17.0 